\title{
Pemanfaatan Food Waste Disposer Berbasis Arduino Uno untuk Pembuatan Pupuk Kompos Limbah Rumah Tangga
}

\author{
${ }^{1}$ Jeka Widiatmanta, ${ }^{2}$ Indyah Hartami Santi \\ Universitas Islam Balitar, Blitar, Indonesia
}

Email: ${ }^{1}$ masjeka@gmail.com, ${ }^{2}$ indyahartamisanti@gmail.com

Tersedia Online di
http://www.jurnal.unublitar.ac.id/i
ndex.php/briliant

Sejarah Artikel

Diterima pada 26 September 2020

Disetujui pada 20 Februari 2021

Dipublikasikan pada 28 Februari 2021

Hal. 163-174

\section{Kata Kunci: \\ Limbah; pupuk kompos; FWD; sensor}

\section{DOI:}

http://dx.doi.org/10.28926/briliant. v3i4.556

\begin{abstract}
Abstrak: Penelitian ini bertujuan untuk menguji alat pengukur kelembaban dan $\mathrm{pH}$ yang berbasis mikrokontroller menggunakan sensor ultrasonik untuk memudahkan pengeloaan limbah organik rumah tangga.Sistem ini terdiri dari beberapa komponen elektronik seperti LCD, Mikrokontroller, Sensor Ultrasonik yang dibangun menggunakan bahasa pemrograman bahasa C. Adapun metode penelitian yang digunakan dalam eksperimen ini adalah pengujian langsung alat. Hasil penelitian lama pencacahan terhadap 6 jenis limbah sejenis hemat waktu 58,6\% dan 99,3\% untuk limbah organik campuran dibanding pencacahan secara manual, dengan kecepatan 103 $\mathrm{kg} / \mathrm{jam}$. Kelembabab masing jenis limbah tomat memiliki kelembaban tertinggi $81 \%$, sedangkan untuk uji $\mathrm{pH}$ tomat, kulit timun, kulit pisang bersifat masam.
\end{abstract}

\section{PENDAHULUAN}

Permasalahan sampah tidak hanya merupakan permasalahan kebersihan, tetapi juga menjadikan permasalahan sosial yang menjadikan rawan konfik di masyarakat. Untuk itu perlu keterlibatan masyarakat secar menyeluruh dalam kegiatan penanganan sampah. Pertumbuhan penduduk dan keamajuan teknologi juga berdampak terhadap jumlah timbunan sampah dalam pada setiap tempat.

Berdasarkan asal timbulan limbah di Kota Blitar sekitar 75\% didominasi dari limbah rumah tangga berupa limbah organik. Limbah organik dapat dimanfaatkan sebagai bahan baku kompos yang selanjutnya bisa dimanfaatkan sebagai pupuk dibidang pertanian. Untuk itu perlu adanya pengelolaan sampah yang baik. Dalam pembuatan pupuk kompos masalah yang sering terjadi adalah persiapan bahan baku kompos. Tingkat kelembaban dan $\mathrm{pH}$ dalam proses pembuatan tidak stabil. Pada tahap hasil berikutnya keseluruhan berpengaruh terhadap hasil kompos, dan jika digunakan dapat menghambat pertumbuhan tanaman dikarenakan kekurangan nitrogen tersedia, sehingga diperlukannya suatu sistem yang dapat proses penyediaan bahan baku tesebut.

Food waste disposer sebuah alat yang dirancang dirancang memperhatikan kelembaban dan derajat keasaman $(\mathrm{pH})$ yang secara otomatis dapat bekerja untuk mengahsilkan pupuk organik menggunakan sensor kelembaban tanah YL-69 (Soil 
Moisture). Dalam implementasinya, probe sensor tersebut dibenamkan kedalam tumpukan bahan pupuk kompos, kemudian sensor akan mendeteksi kelembaban tumpukan kompos tersebut.

Data yang didapatkan sensor diubah kedalam bentuk digital oleh Arduino Uno (mikrokontroler) untuk di tampilkan oleh LCD 2x16 karakter. Dengan menggunakan sistem ini pemantauan telah dilakukan secara otomatis dan didapatkan informasi tentang kelembaban dan $\mathrm{pH}$. Penelitian bertujuan untuk mengetahui sejauh mana food waste disposer dapat membantu pencacah limbah organik di rumah tangga sekaligus memberikan informasi kelembaban dan $\mathrm{pH}$ pada setiap jenis bahan baku kompos.

\section{METODE}

Penelitian dilakukan di Kota Blitar pada bulan April-September 2020. Metode yang digunakan adalah ekperimen terhadap alat food waste disposer . Penelitian memiliki beberapa tahapan seperti, melakukan identifikasi permasalahan yang terjadi pada proses pengolahan limbah organik, identifikasi masalah untuk mencari permasalahan yang ada pada proses pengolahan limbah, analisa masalah untuk mendapatkan solusi dari permasalahan yang sesuai dengan kebutuhun yang diharapkan,analisa rancangan fungsional dilakukan untuk merancang fungsi dan komponen-komponen yang dibutuhkan alat pengolah limbah organik, analisa rancangan struktural ini dilakukan untuk merancang dari kualitas limbah organik sebagai bahan baku kompos. Pengambilan keputusan terhadap alat ini, harus didasarkan pada analisis struktural dan fungsional yang telah dilakukan, selain itu juga harus dipertimbangkan dari segi aspek teknis dan sosial ekonomis.

\section{HASIL}

\section{Data dan Analisis Limbah di Kota Blitar}

Hasil informasi data sampah di Kota Blitar mulai tahun sampai tahun 2018 dapatkan data seperti ada tabel 1 berikut:

Tabel 1. Prosentase Limbah berdasarkan Jenis Limbah di Kota Blitar Tahun 2017-2018 dalam persen

\begin{tabular}{|c|c|c|c|c|c|c|c|c|}
\hline $\begin{array}{c}\text { Sisa } \\
\text { Makana } \\
\text { n }\end{array}$ & $\begin{array}{c}\text { Kayu } \\
\text { Rantin } \\
\text { g } \\
\text { Daun }\end{array}$ & Kertas & Plastik & Logam & Tekstil & $\begin{array}{l}\text { Karet } \\
\text { Kulit }\end{array}$ & Kaca & $\begin{array}{c}\text { Lainny } \\
\text { a }\end{array}$ \\
\hline $25.00 \%$ & $5.00 \%$ & $\begin{array}{c}20.00 \\
\%\end{array}$ & $\begin{array}{c}20.00 \\
\%\end{array}$ & $\begin{array}{c}10.00 \\
\%\end{array}$ & $5.00 \%$ & $5.00 \%$ & $5.00 \%$ & $5.00 \%$ \\
\hline
\end{tabular}

Data: Direktorat Pengelolaan Sampah

Direktorat Jenderal Pengelolaan Sampah, Limbah dan B3

Kementerian Lingkungan Hidup dan Kehutanan

Berdasarkan tabel 1 diatas Kota Blitar sudah melakukan pemilahan terhadap jenis sampah. Adapun jenis sampah diklasifikasikan menjadi bebrapa jenis1)Sisa makanan 2) Kayu dan ranting daun, 3) Kertas, 4) Plastik, 5)Logam , 6)Kain Tektil, 7)Karet Kulit, 8) dan bentuk lainnya yang tidak termasuk jenis di 
atas. Sebagian besar limbah di kota Blitar berasal dari sisa makanan mencapai $25 \%$ dari total sampah yang ada dan $5 \%$ berasal dari kayu ranting dan daun. Kedua limbah tersebut adalah limbah yang dapat diolah sebagai kompos.

Tabel 2. Prosentase Limbah berdasarkan Asal Limbah di Kota Blitar Tahun 2017-2018

\begin{tabular}{|c|c|c|c|c|c|}
\hline $\begin{array}{c}\text { Timbulan } \\
\text { Sampah } \\
\text { Rumah } \\
\text { Tangga }\end{array}$ & $\begin{array}{c}\text { Timbulan } \\
\text { Sampah } \\
\text { Kantor }\end{array}$ & $\begin{array}{c}\text { Timbulan } \\
\text { Sampah } \\
\text { Pasar } \\
\text { Tradisional }\end{array}$ & $\begin{array}{c}\text { Timbulan } \\
\text { Sampah } \\
\text { Pusat } \\
\text { Perniagaan }\end{array}$ & $\begin{array}{c}\text { Timbulan } \\
\text { Sampah } \\
\text { Fasilitas } \\
\text { Publik }\end{array}$ & $\begin{array}{c}\text { Timbulan } \\
\text { Sampah } \\
\text { Kawasan }\end{array}$ \\
\hline $76.92 \%$ & $4.22 \%$ & $11.82 \%$ & $3.53 \%$ & $1.92 \%$ & $1.37 \%$ \\
\hline
\end{tabular}

Data: Direktorat Pengelolaan Sampah

Direktorat Jenderal Pengelolaan Sampah, Limbah dan B3

Kementerian Lingkungan Hidup dan Kehutanan

Tabel 2 berdasarkan asal limbah, limbah di bedakan menjadi limbah rumah tangga, sampah kantor, sampah pasar tradisional, sampat pusat perniagaan, sampah fasilitas publik dan sampah kawasan. Timbulan sampah Kota Blitar berasal dari rumah tangga yang mencapai $76.92 \%$ dan diikuti limbah dari sampah pasar tradisional sebesar $11,82 \%$. Dari data diatas menunjukan sebagain besar timbulan sampah dihasilkan dari limbah rumah tangga dan sampah dari pasar tradisional sedangkan prosentase untuk limbah yang lain relatif lebih sedikit.

Tabel 3. Limbah berdasarkan jumlah timbulan di Kota Blitar Tahun 2017-2018

\begin{tabular}{|c|c|c|c|c|}
\hline $\begin{array}{c}\text { Nama } \\
\text { Kab/Kota }\end{array}$ & Provinsi & Regional & $\begin{array}{c}\text { Jumlah Timbulan } \\
\text { Sampah Harian } \\
\text { Ibu Kota }\end{array}$ & $\begin{array}{c}\text { Jumlah Timbulan } \\
\text { Sampah Harian } \\
\text { Non Ibu Kota }\end{array}$ \\
\hline Kota Blitar & $\begin{array}{c}\text { Jawa } \\
\text { Timur }\end{array}$ & Jawa & 87.91 Ton/hari & 0 Ton/hari \\
\hline
\end{tabular}

Data: Direktorat Pengelolaan Sampah

Direktorat Jenderal Pengelolaan Sampah, Limbah dan B3

Kementerian Lingkungan Hidup dan Kehutanan

Jumlah timbulan di Kota Blitar Tahun 2017-2018 (tabel 2) data sampah yang tertimbun semua dalam setiap hari sebesar 87,91 ton/hari yang ditempatkan dalam satu TPA.

Tabel 4. Limbah berdasarkan jumlah tidak terkelola di Kota Blitar Tahun 2017-2018

\begin{tabular}{|c|c|c|c|}
\hline Jumlah Penduduk & $\begin{array}{c}\text { Luas Wilayah } \\
\text { Administrasi }\end{array}$ & $\begin{array}{c}\text { Jumlah Sampah } \\
\text { Ditimbun TPA }\end{array}$ & $\begin{array}{c}\text { Jumlah Sampah } \\
\text { Tidak Terkelola }\end{array}$ \\
\hline 154714 Jiwa & $32.58 \mathrm{Km} 2$ & $59.81 \mathrm{Ton} / \mathrm{hari}$ & $5.51 \mathrm{~T}$ Ton/hari \\
\hline
\end{tabular}

Informasi dari tabel 4 tidak semua sampah terkirim di TPA, sebesar 5,51 ton/hari masih berada di lingkungan rumah tangga.

\section{Rancangan Alat Food Waste Deponser}

Alat-alat yang digunakan untuk membuat food waste disposer menggunakan sensor ultrasonik, motor, alat pencacah, ulir, dan pengepresan. Sensor ultrasonik, motor, alat pencacah, ulir, dan pengepresan ulir scruw yang akan digunakan sebagai alat food waste disposer. Alat tersebut akan diuji cobakan 
satu persatu untuk mengetahui apakah alat tersebut dapat digunakan dalam mengetahui kualitas kehalusan kompos. alat food waste disposer.dapat dilihat pada gambar 1.

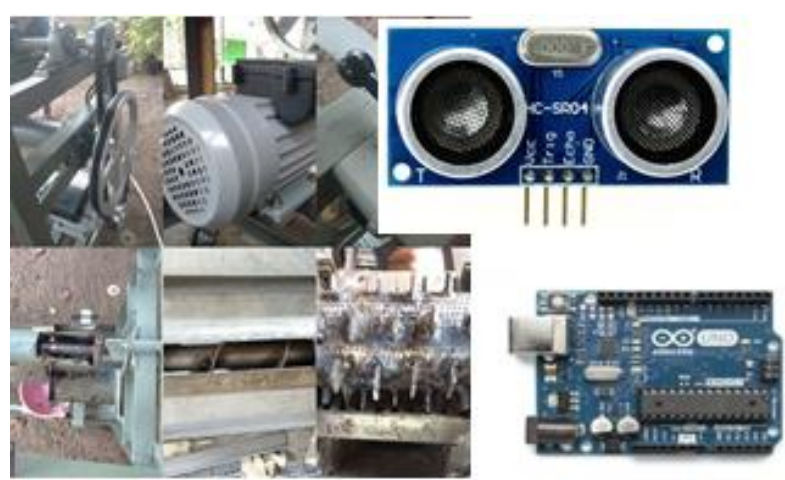

Gambar.1. Alat Yang Dibutuhkan

\section{Pengujian Alat Food Waste Disposer}

Setelah merancang alat dan mempelajari cara kerja, maka dilakukan pengujian dan beberapa pengukuran yang merupakan bagian dari suatau proses perancangan, hal ini dilakukan untuk mengetahui kerja dari alat yang telah dirancang. Pengujian dilakukan berdasarkan blok diagram dari alat tersebut agar dapat diketahui kerja dari setaiap bagian.untuk memastikan bahwa alat yang dibuat bisa digunakan dengan baik, maka dilakukan proses pengujian pada alat dan program yang telah dibuat.beberapa tahapan pengujian yang dilakukan meliputi:

\section{1) Pengujian Sensor Ultrasonik}

Dimana pengujian Sensor Ultrasonik dilakukan pada jangkauan objek apakah sudah dapat mendeteksi bahan baku kompos dengan baik dan bisa berfungsi dengan yang dirancang. Pemasangan sensor ultrasonik dapat dilihat pada gambar 2. berikut:

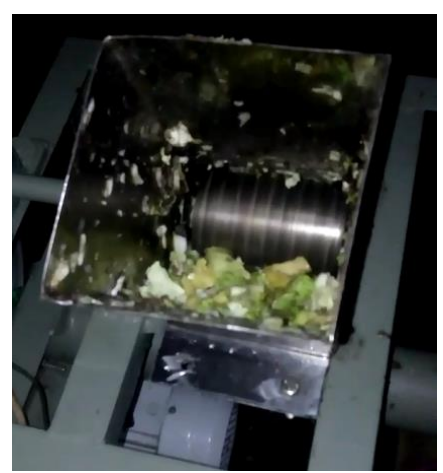

Gambar.2. Pengujian Sensor Ultrasonik

Pengujian sensor ultrasonik akan bekerja dengan jarak $7 \mathrm{~cm}$ dimana saat bahan baku kompos dimasukkan kedalam corong pencacahan dan sensor ultrasonik mendeteksi bahan baku maka alat food waste disposer akan otomatis menyalakan mesin. Pin 6 dan 7 sensor ultrasonik digunakan sebagai jarak jangkauan sensor selanjutnya output ke pin 12 mengaktifkan mesin. Delay dibuat 
5 menit, setelah tidak ada bahan kompos masuk maka alat food waste disposer akan mati secara otomatis.

\section{2) Pengujian Ulir}

Pengujian ulir ini berguna untuk memastikan apakah ulir dapat digunakan untuk mentransmisikan hasil cacahan menuju alat pengepresan. Pengujian ulir disajikan pada gambar 3 .

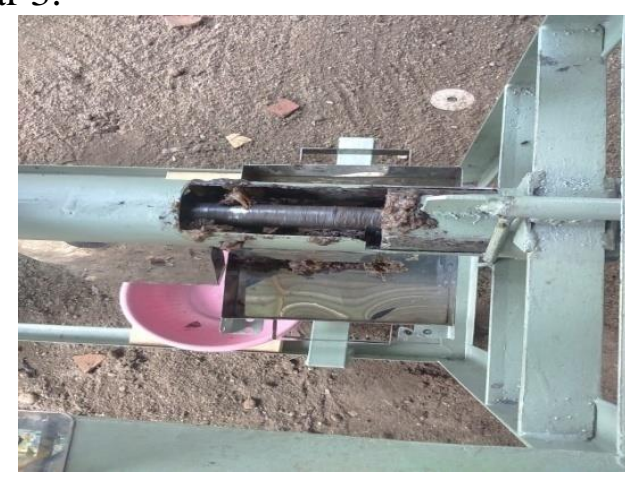

Gambar3. Pengujian Ulir

Hasil pengujian ulir dapat mentransmisikan bahan kompos yang sudah dicacah menuju ke pengepresan ulir scruw. Ulir tidak hanya mentrasmisikan hasil pencacahan bahan kompos namun ulir juga berfungsi untuk menggiling dan membantu memberi tekanan terhadap alat pengepresan.

\section{3) Pengujian Pencacahan}

Pengujian pada pencacahan terdapat pada pemilihan roll mata pemarut dimana pemilihan mata parut adalah pemeran utama dalam menentukan tingkat kualitas kehalusan pupuk yang dihasilkan. Gambar desain serta pengujian alat pencacahan ditunjukan pada gambar 4.

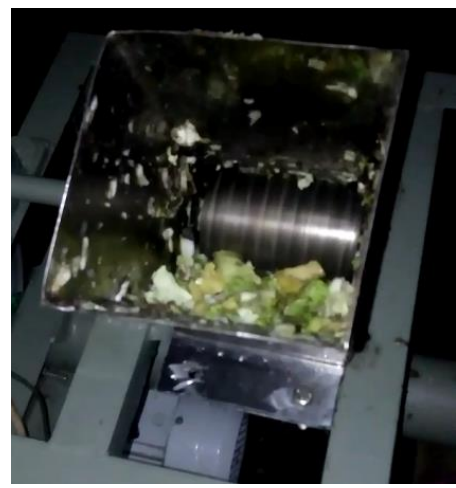

Gambar 4.4 Pengujian Alat Pencacahan

Hasil uji coba pencacahan terhadap bahan kompos yang terdiri dari kulit pisang, selada, kubis, kulit timun, tomat, pare, lama pencacah dirangkum pada tabel 5 .

Tabel 5. Hasil alat pencacahan didapatkan hasil sebagai berikut

\begin{tabular}{|c|c|c|c|}
\hline No. & $\begin{array}{c}\text { Bahan } \\
\text { Kompos }\end{array}$ & $\begin{array}{c}\text { Lama Pencacahan food } \\
\text { waste disposer }\end{array}$ & Keterangan \\
\hline 1. & Kulit Pisang & 4.42 detik & Lembek \\
\hline \multicolumn{4}{|c}{ BRILIANT: Jurnal Riset dan Konseptual } \\
Volume 6 Nomor 1, Februari 2021
\end{tabular}




\begin{tabular}{|c|l|c|c|} 
2. & Selada & 4.47 detik & Berair \\
3. & Kubis & 7.55 detik & Sedang \\
4. & Kulit Timun & 3.39 detik & Berair \\
5. & Tomat & 2.20 detik & Berair \\
6. & Pare & 4.10 detik & Kering \\
& Jumlah & 26.13 detik & - \\
\hline \multicolumn{2}{|c|}{ Rata - rata } & 4.35 detik & - \\
\hline
\end{tabular}

\section{4) Pengujian Alat Pengepresan}

Alat Pengepresan digunakan untuk mengurangi kadar air yang terkandung dalam bahan kompos yang sudah dicacah agar memenuhi syarat tingkat kelembaban pada bahan kompos yang dihasilkan.

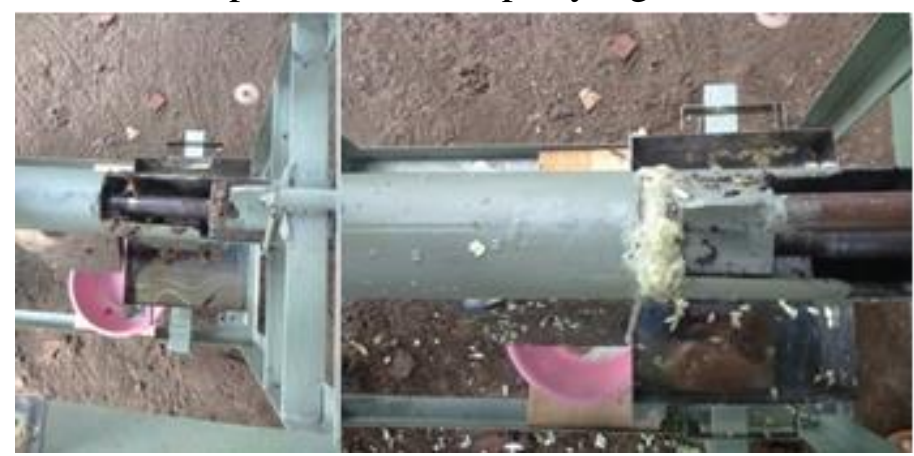

Gambar 4.5. Pengujian Alat Pengepresan

Hasil pengujian (gambar 5) pengepresan menggunakan ulir scruw dapat mengurangi kadar air secara maksimal sehingga bahan kompos yang dihasilkan dapat memenuhi tingkat kelembaban yang dibutuhkan.

\section{5) Pengujian Keseluruhan Alat}

Untuk mengetahui apakah alat food waste disposer yang telah dirancang ini bekerja secara baik maka dilakukan uji coba dengan bagian pertama memasukkan bahan baku kompos pada corong pencacahan untuk menyalakan mesin secara otomatis.

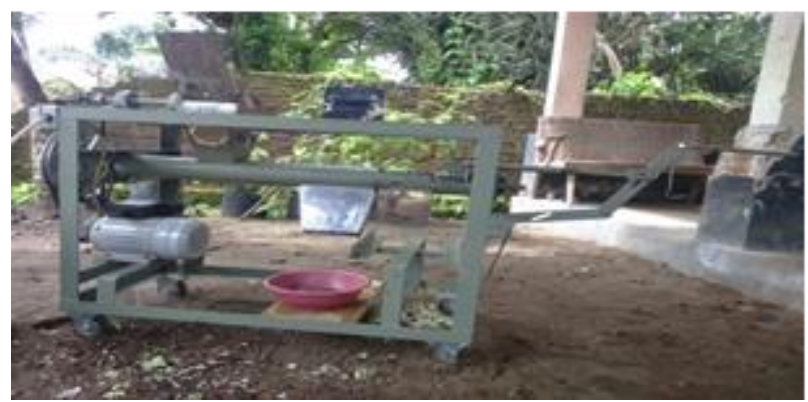

Gambar 6 Pengujian Alat Dan Implementasi Sistem Pada Food Waste Disposer

Tahap kedua mulai pencacahan, yang ketiga bahan kompos yang sudah halus akan didorong oleh ulir untuk menuju ke alat pengepresan, dimana akan menghasilkan bahan kompos yang sudah menggumpal karena berkurangnya air yang terkandung didalamnya

168 BRILIANT: Jurnal Riset dan Konseptual

Volume 6 Nomor 1, Februari 2021 
Jika sudah maka, akan di tes tingkat kelembaban dan keasaman $\mathrm{pH}$ dari bahan kompos yang dihasilkan. Jika telah memenuhi ketentuan maka kompos siap digunakan untuk memupuk tanaman. Desain perancangan alat dan implementasi sistem pada food waste disposer dapat dilihat diatas.

\section{Pengujian Food Waste Disposer pada Limbah Rumah Tangga}

Pengujian tersebut meliputi pengujian tingkat lama pencacahan pada bahan kompos. Pengujian objek penelitian menguji kulit pisang, kulit timun, selada, kubis, tomat, dan pare sebagai bahan untuk pengambilan data. Pengujian objek penelitian meliputi:

\section{Pengujian Enam Limbah sebagai Bahan Baku Kompos}

Pada pengujian yang pertama bahan yang digunakan adalah enam bahan kompos. Bahan kompos tersebut terdiri dari kulit pisang, kulit timun, selada, kubis, tomat dan pare. Pengujian membandingkan antara penumbukan manual dimana alat yang digunakan yaitu tungku dan penumbuk kayu dan alat food waste disposer. Adapun pengujian keenam sempel bahan kompos terdapat pada tabel 6 .

Tabel 6. Pengujian Enam Bahan Kompos Per $1 \mathrm{Kg}$ Bahan Baku

\begin{tabular}{|c|l|c|c|c|}
\hline No. & \multicolumn{1}{|c|}{$\begin{array}{c}\text { Bahan } \\
\text { Kompos }\end{array}$} & $\begin{array}{c}\text { Lama Pencacahan } \\
\text { food waste disposer }\end{array}$ & $\begin{array}{c}\text { Lama } \\
\text { Penumbukan } \\
\text { Manual }\end{array}$ & $\begin{array}{c}\text { Penghematan } \\
\text { Waktu }\end{array}$ \\
\hline 1. & Kulit Pisang & 4.42 detik & 900 detik & $99,5 \%$ \\
2. & Selada & 4.47 detik & 600 detik & $99,2 \%$ \\
3. & Kubis & 7.55 detik & 1200 detik & $99,3 \%$ \\
4. & Kulit Timun & 3.39 detik & 420 detik & $99,1 \%$ \\
5. & Tomat & 2.20 detik & 300 detik & $99,2 \%$ \\
6. & Pare & 4.10 detik & 6.15 detik & $33,3 \%$ \\
& Jumlah & 26.13 detik & 63.15 detik & $58,6 \%$ \\
\hline \multicolumn{2}{|r|}{ Rata - rata } & 4.35 detik & 10.52 detik & $58,6 \%$ \\
\hline
\end{tabular}

Hasil pengujian pada tabel 6 dilakukan pada enam bahan kompos yang berbeda untuk memastikan alat food waste disposer dapat berjalan baik sehingga kualitas waktu sesuai yang dibutuhkan. Keenam bahan kompos yang terdiri kulit pisang, kulit timun, selada, kubis, tomat dan pare. Pengujian kualitas bahan kompos terdeteksi oleh tingkat kehalusan dan lama pencacahan yang dihasilkan oleh alat food waste disposer. Lama pencacahan setiap bahan kompos rata - rata membutuhan waktu 4.35 detik dibandingkan dengan pencacahan menggunakan penumbuk manual yaitu 10.52 detik sehingga alat food waste disposer sangat menghemat waktu hingga 58,6\%.

\section{Pengujian Lama Pencacahan Bahan Kompos Keseluruhan}

Pengujian yang kedua adalah pengujian terhadap keseluruhan atau bisa disebut seluruh bahan kompos pada pengujian pertama dicampur menjadi satu. Pengujian ini meliputi enam bahan kompos adalah kulit pisang, kulit timun, selada, kubis, tomat dan pare. Pengujian alat pencacah ini dilakukan pada tingkat penghancuran sisa sayuran dan buah dengan kecepatan dan lama pencacahan yang 
berbeda akan mendapatkan hasil berupa serpihan yang berbeda pula. Dari semua bahan kompos keseluruhan ini hasil dari pengujian terdapat pada tabel 7 .

Tabel 7. Hasil Waktu Pencacahan Keseluruhan Bahan Kompos Per 1 Kg Bahan Baku

\begin{tabular}{|c|l|c|c|c|}
\hline No. & Bahan Kompos & $\begin{array}{c}\text { Lama Pencacahan } \\
\text { Food Waste Disposer }\end{array}$ & $\begin{array}{c}\text { Lama } \\
\text { Penumbukan } \\
\text { Manual }\end{array}$ & $\begin{array}{c}\text { Penghematan } \\
\text { Waktu }\end{array}$ \\
\hline 1. & Keseluruhan & 5.41 detik & 900 detik & $99,3 \%$ \\
\hline
\end{tabular}

Hasil pengujian pada tabel 7 dilakukan pada keseluruhan bahan kompos yang terdiri kulit pisang, kulit timun, selada, kubis, tomat dan pare. Pengujian kualitas bahan kompos terdeteksi oleh tingkat kehalusan dan lama pencacahan yang dihasilkan oleh alat food waste disposer. Lama pencacahan keseluruhan bahan kompos membutuhan waktu 5.41 detik dibandingkan dengan pencacahan menggunakan penumbuk manual yaitu 900 detik sehingga alat food waste disposer sangat menghemat waktu hingga 99,3\%.

\section{Kapasitas Food Waste Disposer}

Sasaran utama dari uji kinerja alat dan mesin pertanian alaha memperhitugkan kapasitas kerja, kualitas, dan efisiensi kerja dari alat dan mesin pertanian tersebut yang dibandingkan dengan hasil kerja perlatan tradisional yang umum digunakan.

Tabel 8. Kapasitas Food Waste Disposer

\begin{tabular}{|l|c|c|c|c|c|}
\hline Pengulangan & $\begin{array}{c}\text { Berat } \\
\text { Diawal } \\
(\mathrm{kg})\end{array}$ & $\begin{array}{c}\text { Waktu } \\
\text { Pencacahan } \\
(\mathrm{menit})\end{array}$ & $\begin{array}{c}\text { Hasil } \\
\text { Padatan }(\mathrm{kg})\end{array}$ & $\begin{array}{c}\text { Efisiensi } \\
\%\end{array}$ & $\begin{array}{c}\text { Kapasitas } \\
\text { Pencacahan } \\
(\mathrm{kg} / \mathrm{jam})\end{array}$ \\
\hline Ulangan 1 & 10 & 5.22 & 8.3 & 83 & 95.40 \\
Ulangan 2 & 10 & 5.33 & 9.1 & 91 & 102.44 \\
Ulangan 3 & 10 & 5.31 & 8.6 & 86 & 97.18 \\
Ulangan 4 & 10 & 5.12 & 8.8 & 88 & 103.13 \\
Ulangan 5 & 10 & 5.22 & 9 & 9 & 103.45 \\
Jumlah & 50 & 26.2 & 43.8 & 438 & 501.59 \\
\hline Rata-rata & 10 & 5.24 & 8.76 & 87.6 & 100.32 \\
\hline
\end{tabular}

Berdasarkan hasil pencacahan limbah dari lima kali ulangan dapatkan hasil ratarata dari pengolahan $10 \mathrm{~kg}$ bahan baku limbag waktu pencacahan 5,24 menit untuk mengolah limbah rumah tangga berupa sayur dan buah-buahan rata-rata efisiensi 87,6\%, artinya dalam $1 \mathrm{~kg}$ bahan limbah organik dari rumah tangga akan diperoleh bahan $8,7 \mathrm{~kg}$ bahan kompos, kapasitas alat rata-rata $100 \mathrm{~kg} / \mathrm{jam}$.

\section{Pengujian Kelembaban dan pH Bahan Kompos dengan Food Waste Disposer}

Data yang dianalisis pada penelitian ini meliputi analisis terhadap setiap jenis limbah organik setiap jenis sayur atau buah -buahan masing -masing diuji kelembaban dan derajat keasamannya. Dari hasil data yang uji coba pada berbagai buah sayuran diperoleh data seperti tabel berikut 
Tabel 9. Hasil Uji Kelembaban pada Food Waste Disposer berbagai Limbah Buah dan Sayuran dalam persen

\begin{tabular}{|l|r|r|r|r|r|r|}
\hline & Tomat & \multicolumn{1}{|c|}{ Kubis } & \multicolumn{1}{c|}{ Pare } & Selada & $\begin{array}{c}\text { Kulit } \\
\text { Timun }\end{array}$ & $\begin{array}{c}\text { Kulit } \\
\text { Pisang }\end{array}$ \\
\hline Ulangan 1 & 85 & 9 & 54 & 51 & 66 & 67 \\
Ulangan 2 & 80 & 8 & 56 & 49 & 70 & 72 \\
Ulangan 3 & 78 & 9 & 52 & 44 & 63 & 67 \\
Ulangan 4 & 79 & 8 & 59 & 55 & 67 & 69 \\
Ulangan 5 & 83 & 10 & 53 & 50 & 70 & 66 \\
Jumlah & 405 & 44 & 274 & 249 & 336 & 341 \\
\hline Rata-rata & 81.00 & 8.80 & 54.80 & 49.80 & 67.20 & 68.20 \\
\hline
\end{tabular}

Hasil dari Food Waste Disposer didapatkan informasi bahwa setiap sayuran memiliki kelembaban berbeda-beda. Dari tabel 8 didapatkan hasil buah tomat memiliki kadar air yang tinggi $81 \%$, tanaman kubis memliki kadar kelembaban yang paling rendah $8,80 \%$.

Tabel 10. Hasil Uji pH pada Food Waste Disposer berbagai Limbah Buah dan Sayuran

\begin{tabular}{|l|r|r|r|r|r|r|}
\hline & Tomat & Kubis & \multicolumn{1}{c|}{ Pare } & Selada & $\begin{array}{c}\text { Kulit } \\
\text { Timun }\end{array}$ & $\begin{array}{c}\text { Kulit } \\
\text { Pisang }\end{array}$ \\
\hline Ulangan 1 & 2.6 & 12.5 & 6.34 & 6.95 & 4.4 & 4.44 \\
Ulangan 2 & 2.71 & 12.4 & 6.53 & 7.2 & 4.33 & 4.23 \\
Ulangan 3 & 2.5 & 12.6 & 6.21 & 7 & 5 & 4.22 \\
Ulangan 4 & 2.7 & 13 & 6.34 & 6.88 & 4.7 & 4.1 \\
Ulangan 5 & 2.51 & 12.83 & 6.3 & 7.13 & 4.63 & 4.65 \\
Jumlah & 13.02 & 63.33 & 31.72 & 35.16 & 23.06 & 21.64 \\
\hline Rata-rata & 2.60 & 12.67 & 6.34 & 7.03 & 4.61 & 4.33 \\
\hline
\end{tabular}

Dari hasil uji derajat keasaman buah tomat, kulit timun, kulit pisang, termasuk bahan baku kompos yang bersifat sangat masam ( $\mathrm{pH}$ diatas 6), sedangkan pare dan selada netral, sedangkan kubis bersifat basa. Keasaman atau $\mathrm{pH}$ dalam tumpukan kompos juga mempengaruhi proses pengomposan dan dari berbagai hasil pengamatan memperlihatkan bahwa kondisi $\mathrm{pH}$ tanah sekitar netral (6,5-7,5) adalah yang Food Waste Disposer dapat digunakan sebagai petunjuk awal sebelum proses pengomposan di mulai.

Tabel 11. Spesifikasi kompos berdasarkan SNI 19-7030-2004.

\begin{tabular}{|l|l|c|c|c|}
\hline No & \multicolumn{1}{|c|}{ Parameter } & Satuan & Minimum & Maksimum \\
\hline 1 & Kadar Air & $\%$ & - & 50 \\
\hline 2 & Temperatur & ${ }^{\circ} \mathrm{C}$ & suhu air tanah & \\
\hline 3 & Warna & kehitaman & & \\
\hline 4 & Bau & berbau tanah & & \\
\hline 5 & Ukuran partikel & $\mathrm{mm}$ & 0,55 & 25 \\
\hline 6 & Kemampuan ikat air & $\%$ & 58 & - \\
\hline 7 & $\mathrm{pH}$ & 6,80 & 7,49 & 1,5 \\
\hline 8 & Bahan asing & $\%$ & $*$ & \\
\hline \multicolumn{4}{|l|}{ Keterangan : * Nilainya lebih besar dari minimum atau lebih kecil dari maksimum } \\
\hline
\end{tabular}


Agar kompos yang dihasilkan mempunyai kualitas baik, maka diperlukan adanya standar yang digunakan sebagai acuan, salah satunya adalah SNI 19-70302004 tentang spesifikasi kompos yang disampaikan pada tabel 11 .

\section{PEMBAHASAN}

\section{A. Permasalah Sampah di Kota Blitar}

Sumber penghasil limbah menurut A.K. Haghi (2010). adalah: 1)Limbah rumah tangga, biasa disebut juga limbah domestik 2)Limbah industry merupakan limbah yang berasal dari industri pabrik.3)Limbah pertanian merupakan limbah padat yang dihasilkan dari kegiatan pertanian.4)Limbah konstruksi didefinisikan sebagai material yang sudah tidak digunakan lagi dan yang dihasilkan dari proses konstruksi, perbaikan atau perubahan 5)Limbah radioaktif, limbah radioaktif berasal dari setiap pemanfaatan tenaga nuklir, baik pemanfaatan untuk pembangkitan daya listrik menggunakan reaktor nuklir.

Hampir semua kabupaten/kota yang ada di Indonesia selalu dihadapkan dengan pemasalahan sampah, perubahan jumlah penduduk dan pola perubahan konsumsi di masyarakat yang menimbukan volume, jenis karateristik sampah yang semakin beragam. Data penelitian berdasarkan jenis limbah di Kota Blitar didominasi dari sisa makanan sebesar $25 \%$ dan $75 \%$ asal limbah berasal dari sampah rumah tangga. Jumlah komposisi dan karakteristik sampah tidak terlepas dari pola kecenderungan konsumsi masyarakat itu sendiri (Damanhuri, 1:2016).

Pemerintah Kota Blitar telah menerapkan strategi tumpuan bagi suksesnya pengelolaan sampah kota, dan dalam program jangka panjang setiap rumah tangga disarankan mengelola sendiri sampahnya melalui program $3 \mathrm{R}$ (reduce, reuse, dan recycle) yaitu dengan mengurangi, menggunakan kembali atau didaur ulang (Heru Subaris, 2016) tetapi belum sepenuhnya target teresebut terpenuhi. Hal ini ditunjukan dari data timbunan sampah harian sebesar 87.91 ton/hari yang tertampung di TPA dan 5.51 ton/hari sampah yang tidak terkelola.

Jumlah sampah yang besar tidak lepas dari presepsi masyarakatat tentang sampah, Sejalan dengan pendapat Hermawan (2005). Persepsi masyarakat menjadi salah satu penentu tingkat partisipasi masyarakat karena persepsi merupakan proses psikologis yang tidak terlepas dari diri masing-masing individu yang berfungsi membentuk sikap dan menentukan keputusan untuk bertindak. Apabila persepsi masyarakat terhadap pengelolaan sampah baik, maka partisipasi masyarakat dalam pengelolaan sampah akan meningkat.

Faktor-faktor yang mempengaruhi persepsi masyarakat berasal dari dalam diri individu dan hubungannya dengan lingkungan di mana ia tinggal. Faktor yang berasal dari dalam individu berupa usia, jenis kelamin, tingkat pendidikan, pekerjaan, pendapatan, pengetahuan dan pegalaman.

\section{B. Pemanfaat Food Waste Disposer untuk Pengelolaan Limbah}

Salah satu bentuk pengelolaan sampah organik adalah diolah menjadi pupuk kompos. Pembuatan pupuk kompos dapat mengurangi masalah sampah sekaligus menciptakan nilai ekonomi dari sampah.Salah satu alasan mengapa masyarakat tidak mengelola sampah secara mandiri adalah kurang tersedianya 
waktu dan peralatan untuk melakukan kegitan tersebut. Perancangan alat Food Waste Disposer membantu memberikan solusi atas permasalah di atas.

Dari hasil data uji coba alat didapakan informasi dengan menggunakan Food Waste Disposer memiliki kapasitas 100,32 kg/jam untuk mencacah limbah memerlukan waktu yang lebih pendek apabila dibandingkan pencacahan yang dilakukan secara manual. Lama mencacah secara manual diperlukan waktu 10,2 detik/kg sedangkan menggunakan Food Waste Disposer memerlukan waktu 4,35 detik. Artinya dengan menggunakan alat akan menghemat waktu 58,6\%. Sedangkan untuk uji coba menggunakan limbah tanpa pemilahan lebih menghemat waktu 99,3\%. Keuntungan penggunaan alat ini adalah waktu untuk mengerjakan tugas akan lebih cepat. Sesuai dengan penelitian I Putu Darwmawa (2015) iptek bertujuan untuk mengatasi berbagai masalah bagi masyarakat, dengan teknologi bisa meningkatkan produktiftas kinerjanya.

Hasil uji coba terhadap obyek penelitian yang terdiri dari limbah tomat, kubis, pare, selada, kulit timun, dan kulit pisang yang selanjutnya digunakan sebagai bahan baku kompos diperoleh setiap jenis limbah berbeda memiliki kelembaban dan $\mathrm{pH}$ yang tidak sama. Tomat memiliki kadar air yang tinggi $81 \%$, sedangkan kubis memiliki kadar kelembabab yang terendah. Derajat keasaman tomat, kulit timun, kulit pisang bersifat masam. Informasi kelembaban dan $\mathrm{pH}$ Food Waste Disposer dapat terbaca secara otomatis pada layar lcd sehingga dengan adanya teknologi data bahan kompos yang diperlukan diperoleh dengan cepat. Dengan informasi yang didapatkan diharapkan kompos yang berkualitas baik diperoleh dari bahan baku yang bermutu baik pula.

Kandungan air yang ada pada bahan baku, merupakan salah satu kunci keberhasilan pembuatan kompos adalah sesuai hasi penelitian (Dian Asri Puspa Ratna,2017) kandungan air sangat berpengaruh terhadap kelangsungan hidup mikroorganisme. Pada umumnya mikroorganisme tidak dapat hidup apabila kekurangan air. Apabila kelembaban dibawah 40\%, proses dekomposisi bahan organik akan melambat. Demikian pula pendapat Sindi Martina Hastuti (2017) apabila kelembaban dibawah 30 persen, proses dekomposisi praktis akan terhenti. Akan tetapi, apabila kelembaban > 60 persen, maka yang terjadi adalah keadaan anaerob (tanpa oksigen), yang akan menyebabkan timbulnya aroma tidak sedap (masam). Proses pengoposan menghendaki kelembaban ideal antara 50 60 persen. Keadaan ini merupakan keadaan ideal untuk memulai proses pengomposan.

Nilai pH antara 5,5 dan 8,5 adalah kisaran $\mathrm{pH}$ optimal untuk mikroorganisme kompos. Ketika bakteri dan jamur menguraikan materi organik dalam kompos, maka bakteri dan jamur tersebut akan mengeluarkan asam organik. Ketika $\mathrm{pH}$ turun, pertumbuhan jamur akan meningkat, diikuti oleh dekomposisi lignin dan selulose. Pengomposan pada penelitian ini adalah dalam kondisi aerob, dimana ada udara yang masuk sehingga akan mengembalikan $\mathrm{pH}$ ke kisaran yang sesuai.

\section{KESIMPULAN}

Kesimpulan dari penelitian ini adalah Food Waste disposer berbasis Arduino Uno dapat digunakan untuk untuk memudahkan pengeloaan limbah 
organik rumah tangga. Hasil pengujian terhadap alat lama pencacahan terhadap enam jenis limbah organik dapat menghemat waktu 58,6\% dan 99,3\% untuk limbah organik campuran dibanding pencacahan secara manual, dengan kapasitas $103 \mathrm{~kg} / \mathrm{jam}$. Kelembabab masing jenis limbah tomat memiliki kelembaban tertinggi $81 \%$, sedangkan untuk uji $\mathrm{pH}$ tomat, kulit timun, kulit pisang bersifat masam.

\section{SARAN}

Secara umum Food Waste disposer berbasis Arduino Uno dapat diaplikasikan untuk membantu proses pengelolaan limbah organik dalam rumah tangga, bentuknya yang portabel memudahkan dipindahkan dari tempat yang satu ke tempat yang lainnya. Keterbatasan alat ini hanya dapat memonitor kelembaban dan $\mathrm{pH}$, berdasarkan analisis dilapangan alat belum bisa mendeteksi ukuran partikel, aerasi, porositas, suhu yang juga faktor-faktor penting dalam pengomposan, sehingga bisa dikembangkan pada penelitian berikutnya.

Meskipun jenis limbah sudah terpisah antara limbah organik dan non organik, tetapi sampai pada saat ini belum didapatkan data limbah organik belum dipisahkan jenisnya secara lebih detail berdasarkan jenis sayur atau buah. Dari hasil penelitian setiap jenis limbah organik memiliki karatteristik sendiri-sendiri, pada pengembangan berikutnya dapat dikembangan kajian dibidang teknologi, sosial, budaya, dan ekonomi.

\section{DAFTAR RUJUKAN}

A.K. Haghi. (2010). Waste Management. Canada: Nova Science.

Darmawa, I Putu, dkk. Pemanfaatan Teknologi Tepat Guna Berupa Mesin

Pencacah Pakan Ternak Kambing Di Desa Sepang Kabupaten

Buleleng. Bhakti Persada Jurnal Aplikasi IPTEKS, [S.1.], v.1, n.1, p.81, feb. 2017. ISSN 2580-5606. Available at:<http://ojs.pnb.ac.id/index.php /BP/article/view/251>. Date accessed: 10 jan. 2021.

Denny Eko Prisanto, 2015. Sampah Urusan Kita Bersama. http://dlh.blitarkota. go.id /detailpost/sampah-urusan-kita-bersama?lang=gb

Dian Asri Puspa Ratna, et all, 2017. Pengaruh Kadar Air Terhadap Proses Pengomposan Sampah Organik Dengan Metode Takakura. Teknik Mesin Univesitas Mercubuana. 2017;6(2):124-128 .DOI 10.22441/jtm.v6i2.1192

Hermawan Y. 2005. Hubungan Antara Tingkat Pendidikan Dan Persepsi Dengan Perilaku Ibu Rumah Tangga dalam Pemeliharaan Kebersihan Lingkungan. Bumi Lestari Journal of Environment. http://ojs.unud.ac.id/index.php/blje/article/view/2411/ 1639

Heru Subaris dkk, 2016. Sedekah Sampah Untuk Pemberdayaan Masyarakat. (Yogyakarta: Parama Publishing dan Cita Sehat Foundation; Nuha Medika, 2016), hlm. 31

Sindi Martina Hastuti1, Ganjar Samudro2, Sri Sumiyati3,2017. Pengaruh Kadar Air Terhadap Hasil Pengomposan Sampah Organik Dengan Metode Composter Tub. Departemen Teknik Lingkungan, Fakultas Teknik, Universitas Diponegoro Semarang, Vol. 06, No. 2, Maret 2017, hal 17. 